DOI https://doi.org/10.30525/978-9934-588-81-5-1.11

\title{
FEATURES OF PSYCHOEMOTIONAL CONDITION IN PREGNANT WOMEN AFTER APPLICATION OF ASSISTED REPRODUCTIVE TECHNOLOGIES
}

\author{
Vygivska L. M. \\ $P h D$,
}

Associate Professor at the Department of Obstetrics and Gynecology № 3

Bogomolets National Medical University

Maidannyk I. V.

$P h D$,

Associate Professor at the Department of Obstetrics and Gynecology № 3

Bogomolets National Medical University

Chorna O. A.

$P h D$,

Associate Professor at the Department of Obstetrics and Gynecology № 3

Bogomolets National Medical University

Oleshko V. F.

$P h D$,

Assistant at the Department of Obstetrics and Gynecology № 3

Bogomolets National Medical University

Pozniak D. O.

5th year Student

Bogomolets National Medical University

Kyiv, Ukraine

The issue of reproductive health of Ukrainian nation preserving is very acute nowadays $[1,2]$. The leading factor which negatively affects its formation is the rapid decrease in the birth rate, the increase of infertility in population, complicated somatic and obstetric-gynecological anamnesis, prolonged stress, and a high rate of complicated pregnancies and labors.

That is why special attention should be paid to infertile couples which are almost about 1 million in the country today $-6.8 \%$ of the total number of married couples [5]. The state of infertility increase is a world speared tendency today, which leads to a rapid research of the latest modern methods of its treatment. In the General population of pregnant women, the 
proportion of women whose pregnancy became as the result of the Assisted Reproductive Technologies (ART) application has increased $[4,9,10]$.

The ART introduction in the daily practice of infertility treatment has improved demographic indicators and increased the birth rate in Ukraine more than for four times in recent years [7]. At the same time, pregnancy resulting from the ART application usually has a high risk of a complicated course with the development of placenta-associated complications: miscarriage and prematurity, preeclampsia, fetal growth retardation, and fetal distress [1,2].

The psychoemotional condition of the pregnant woman is of particular importance for prolonging pregnancy and the normal course of labor [8]. There is no doubt about the negative impact of chronic stress on the pregnancy course in woman with a history of infertility. Violation of adaptive mechanisms which are aimed at restructuring of the functional systems during pregnancy and before labors contributes to an increase in the frequency of obstetric and perinatal complications [3, 4].

The Purpose of Research: to study the features of the psychoemotional condition in pregnant women after assisted reproductive technologies application in the dynamics of pregnancy

Materials and Methods of research. 130 pregnant women of two clinical groups were comprehensively examined in the dynamics of prospectivestudy: the main group consisted of 80 women with a history of endocrine infertility who successfully completed the ART treatment cycle, and the control group consisted of 50 pregnant women with spontaneous fertilization. All pregnant women of the study groups were examined in accordance with the quality standards of the Ministry of Health of Ukraine Order No. 417 from 15.07.2011 "Guidelines for providing outpatient obstetric and gynecological care"

In order to determine the psychoemotional condition of pregnant women in the study groups, a clinical interview was conducted in the screening mode by STAI questionnaires and the "Pregnant woman attitude Test" according to the I. V. Dobriakov's method [6].

The Results of Research. According to the results of the studies, the average age of pregnant women in the main $(26.7 \pm 1.8$ years $)$ and control $(28.5 \pm 4.3$ years) groups did not have significant differences $(p>0.05)$. In the vast majority of pregnant women in the main group -69 cases $(86.3 \%)$, infertility was the result of the long-term course of polycystic ovary syndrome (PCOS), in particular, against the background of hyperandrogenism of mixed genesis -8 cases $(10.0 \%)$. The proportion of genital endometriosis -7 cases $(8.6 \%)$ and hyperprolactinemia -4 cases $(5.0 \%)$ in the struc- 
ture of infertility causes in women of the main group did not differ significantly. The main group was dominated by women with secondary infertility $(60.0 \%)$, who had a history of early spontaneous miscarriages in $72.9 \%$ of cases (35 women), 8 women $(16.7 \%)$ had a miscarriage that did not take place, and 5 women $(10.4 \%)$ had an artificial abortion. The period of infertility in observed women ranged from 3.8 to 7.3 years and was in average $5.6 \pm 2.3$ years. In women with infertility due to PCOS and genital endometriosis, the duration of infertility period was prolonged because of a combination of hormonal and surgical treatment.

For pregnant women with a history of infertility, a long period of treatment which occurred with the use of combined and valuable methods, and pregnancy is associated with ART application, a condition of chronic stress is characteristic.

According to the results of the STAI test, the average Reactive Anxiety (RA) score in the main group exceeded the same indicator of the control group by an average of 2.1 times and amounted to 51. Low RA level was typical for 24 (30.0\%), medium RA for 15 (18.8\%), and high RA for $41(51.2 \%)$ pregnant women of the main group. Among the control group women prevailed pregnants with low RA score $-26(52.0 \%$; $\mathrm{p}<0.05)$. The proportion of control group pregnant women with moderate and high RA reached $34.0 \%$ (17 cases) and $14.0 \%$ (7 cases) ( $\mathrm{p}<0.05)$ respectively. In accordance with the test results, a significant difference was found in the Personal Anxiety (PA) - 52 and 31 points. A low PA level was observed in every third pregnant woman in the main group (33.8\%; in the control group - 66.0\%; p $<0.05$ ), medium PA - in almost every second (46.3\%; in the control group - 22.0\%; $\mathrm{p}<0.05$ ), which is almost 2 times higher than in control group pregnant women. The frequency of high PA in pregnant women in the main group also exceeded the control group values and was $20.0 \%$ (control group-12\%; $\mathrm{p}<0.05$ ).

According to the I.V. Dobriakov's test results, a moderate and high PA and RA levels was detected in pregnant women of the main group. For $8(10.0 \%)$ women who became pregnant as a result of ART application the optimal Psychological Component of Gestational Dominant (PCGD) was typical, hypogestognosic type - in 28 (35.0\%), euphoric - in $26(32.5 \%)$, anxious - in $12(15.0 \%)$ and depressive - in $6(7.5 \%)$-pregnant women. In control group pregnant women the optimal PCGD type was registered in $27(54.0 \%$; p $<0.05)$, euphoric - in $7(14.0 \%)$, and hypogestognosic - in $16(32.0 \%)$ cases. Other types did not score enough points and were not taken into account during the results calculation. 
Conclusions. The results of the conducted studies confirm that in the main group pregnant women compensatory and adaptive mechanisms of pregnancy regulation can most likely activate the biosynthesis of stressassociated hormones.

The results of STAI survey indicated medium and high levels of personal and reactive anxiety in the main group women, which has a pathological effect on the course of pregnancy and gestational dominant formation.

For the vast majority of the main group pregnant women were characteristic hypogestognosic $-35.0 \%$ and euphoric - 32.5\% PCGD types which confirm the presence of neuropsychic and affective disorders.

For women whose pregnancy become as a result of ART cycles application, it is advisable to conduct psychologist and psychotherapist consulting in order to correct the identified disorders and improve the perinatal consequences.

\section{References:}

1. Адамов М.М. Вагітність і пологи після застосування допоміжних репродуктивних технологій, виконаних за відсутності та наявності маткових труб. Здоровье женщины. 2011. 5. 159-160.

2. Александрова Н.В., Баев О.Р., Иванец Т.Ю. Преждевременные роды при беременности, наступившей с использованием вспомогательных репродуктивных технологий. Пути профилактики. Акущерство и гинекология. 2012.4 (2). 33-38.

3. Анчева I.А. Психопрофілактика стресу під час вагітності та пологів. Здоровье женщины. 2017. 5(121). 32-34.

4. Астахов В.М., Билим А.В. Особливості перебігу вагітності, пологів та післяпологового періоду у жінок зі змішаною інфекцією геніального тракту в анамнезі. Педіатрія, акушерство та гінекологія. 2011. (3). 85-89.

5. Вигівська Л.М., Никонюк Т.Р., Ковалюк Т.В., Ластовецька Л.Д. Стан системи гемостазу та ендотеліального статусу у вагітних після застосування ДРТ. 3б. пр. Асоџіачїі акушерів-гінекологів Украӥни. 2016. (2). 109-114.

6. Добряков И.В., Прохоров В.Н., Прохорова О.В. Психологическая диагностика в перинатальной психологии. Диагностика в медицинской (клинической) психологии: современное состояние и перспективы. Коллективная монография. 2016. 118-132.

7. Лесовська С.Г. Стан впровадження допоміжних репродуктивних технологій в Україні. Слово о здоровье. 2017. 8. 12-16. 
8. Майдан I.С. Психоемоційні порушення у жінок як предиктор розвитку непліддя. Слово о здоровье. 2017. 12. 41-44.

9. Щорічна доповідь про стан здоров'я населення, санітарноепідемічну ситуацію та результати діяльності системи охорони здоров'я України. 2015 рік / за ред. В. В. Шафранського; МОЗ України; ДУ «УІСД МОЗ України». - К.. 2016. 452.

10. Michael A.E., Papageorghiou A.T. Potential significance of physiological and pharmacological glucocorticoids in early pregnancy. Human Reproduction Update. 2008.14 (5). 497-517.

DOI https://doi.org/10.30525/978-9934-588-81-5-1.12

\title{
PRESEPSIN IS A DIAGNOSTIC MARKER OF THE SEVERITY OF SEPSIS
}

\author{
Voloboyeva A. $O$. \\ Department of Anesthesiology \\ Communal Municipal Clinical Hospital № 8 \\ Lviv, Ukraine \\ Fuss Yu. O. \\ Department of Surgery \\ Regional Hospital in Pustomyty \\ Pustomyty, Lviv region, Ukraine
}

Introduction. Sepsis is a complex and urgent problem of modern medicine around the world $[1,2]$. Early diagnosis of sepsis allows you to diagnose in time, assess the patient's condition, begin treatment. Biomarkers are important in the early diagnosis of sepsis, indicating the presence or absence of this infectious complication [3, 4]. Presepsin (PSP) is a new biomarker of bacterial and fungal systemic infections [5].

Material and methods. 96 patients were studied. The mean age of patients was $63.2 \pm 2.35$ years. All patients were treated in PCRL and $8 \mathrm{MCL}$ from 2018-2019. Patients were divided into two groups: I - 51 (53\%) patients with abdominal sepsis, II - 45 (47\%) patients with other inflammatory diseases (appendicitis, cholecystitis, etc.). The level of PSP was quantified on an immunochemiluminescent analyzer Pathfast (Mitsubishi Chemical Medience Corporation, Japan). All patients received antibiotic therapy. 